\title{
Analisis Keamanan Dalam Desain Database PMB (Penerimaan Mahasiswa Baru) dengan MySQL
}

\author{
Security Analysis in Database Design PMB (New Admissions) \\ with MySQL \\ Sofyan Pariyasto*1, Ema Utami², Suwanto Raharjo ${ }^{3}$ \\ 1,2Program Pasca Sarjana Universitas Amikom Yogyakarta, 3IST AKPRIND Yogyakarta \\ E-mail: *1 sofyanpariyasto@gmail.com, 2ema.u@amikom.ac.id, \\ ${ }^{3}$ wa2n@akprind.ac.id
}

\begin{abstract}
Abstrak
Keamanan dalam desaian suatu database merupakan hal yang sangat penting untuk diterapkan dalam membangun sebuah sistem informasi. Sering kali dalam implementasi keamanan database tidak begitu diperhatikan, baik dari segi tipe data, panjang data, maupun paramter yang berkaitan dengan transaksi data. Kesalahan dalam desain database biasanya baru akan disadari pada saat aplikasi sudah selesai dan sudah digunakan. Untuk memastikan sebuah sistem informasi berjalan dengan lancar maka akan digunakan analisa data berdasarkan rentang data tertinggi dan data terendah. Dengan menggunakan analisa rentang data maka data yang nilainya lebih rendah dari paremeter yang ditentukan akan dirubah ke nilai terendah yang sesuai dengan paramter. Begitu juga data yang nilainya lebih tinggi dari paramter yang telah ditentukan akan dirubah ke nilai tertinggi yang sesuai dengan parameter. Dari hasil pengujian yang dilakukan sebelum adanya filter check dan patameter tipe data dengan memasukan data yang berupa huruf, angka minus serta angka yang melebihi batas atas pada kolom nilai, data masih bisa tersimpan ke database. Pengujian selanjutnya dilakukan dengan memasukan angka 2,-3,-4,-5,-7,-7 serta angka diatas ambang batas atas 12,13,14,15,16,17, dari hasil pengujian yang dilakukan dapat disimpulkan bawah sebuah database dengan fungsi trigger jauh lebih aman dibandingkan dengan database yang hanya menerapkan fungsi pembatasan berdasarkan tipe datanya saja.
\end{abstract}

Kata Kunci — Keamanan Desain Database MySQL, Analisis Keamanan Database

\begin{abstract}
Security in the design of a database is very important to be applied in building an information system. Often in the implementation of a database security is not given much attention, both in terms of data types, length, and parameters relating to data transactions. Errors in database design are usually only noticed when the application is complete and has been used. To ensure an information system runs well, data analysis will be used based on the highest and lowest data ranges. By using data range analysis, data whose value is lower than the specified parameter will be changed to the lowest value in accordance with the parameters. Data whose value is higher than predetermined parameters will be changed to the highest value in accordance with parameters. Results of tests conducted before the filter check and data type patameter by entering data in the form of letters, minus numbers and numbers that exceed the upper limit in the value column, data can still be saved to database. Further testing is done by entering the numbers $-2,-3,-4,-5,-7,-7$ and numbers above the upper threshold of 12,13,14,15,16,17, from some of the results of tests conducted can be concluded below a database with a trigger function is more secure than a database that only applies restrictions based on its data type.
\end{abstract}

Keywords — Security Database Design MySQL, Security Analysis Database 


\section{PENDAHULUAN}

Database merupakan kumpulan data yang di kelompokan kedalam masing-masing kelompok yang saling berkaitan antara satu dengan yang lainnya. Database secara garis besar dibedakan menjadi dua bagaian, yaitu database flat dan database relasional. Database flat adalah sebuah database dimana masing-masing data didalamnya berdiri sendiri dan tidak saling berelasi, sehingga setiap transaksi yang dilakukan dalam sebuah tabel baik itu pengisian data, penghapusan maupun perubahan data tidak akan berpengaruh ke tabel yang lain. Sedangkan database relasional adalah database yang saling berelasi satu dengan yang lainnya, sehingga jika ada transaksi data dalam sebuah tabel akan berpengaruh ke tabel yang terkait [1].

Suatu Database Management System (DBMS) merupakan sekumpulan data yang dapat dimanipulasi baik itu penambahan, penghapusan maupun perubahan data, serta sebuah perangkat lunak yang berfungsi sebagai antara muka pengguna untuk melakukan kegiatan transaksi data dimana database dalam sebuah DBMS harus saling berelasi satu dengan yang lainnya. Jadi dapat disimpulkan bahwa database merupakan sekumpulan file-file ataupun data yang saling berelasi satu dengan yang lainnya, dimana untuk menghubungkan sebuah data dengan data lainnya dalam relasi tersebut dibutuhkan data pengubung (key) [2].

Salah satu peran database yaitu harus mempu memenuhi kebutuhan pengguna dalam memberikan berbagai informasi dan data terkait sistem informasi yang digunakan Database harus mampu memenuhi kebutuhan tersebut baik saat ini maupun dimasa mendatang. Sebuah database juga harus memiliki kemapuan dalam proses pembuatan pencadangan (Backup) karena data harus tetap dijaga sehingga dapat diakses kapanpun [3].

Dalam sebuah sistem informasi tidak terlepas dari keberadaan sebuah database. Dimana database ini memiliki fungsi untuk menampung data-data yang berkaitan dengan sebuah sistem informasi. Seiring dengan berjalannya sebuah sistem informasi tentu pertambahan jumlah data yang tersimpan dalam database juga akan semakin meningkat, hal ini tentu menjadi perhatian penting dimana dengan jumlah data yang terus meningkat dan bersifat rahasia tersebut maka dibutuhkan suatu pengamanan khusus pada database, baik Backup, antisipasi SQL Injection maupun penanganan khusus terhadap transaksi antar tabel baik itu insert, update dan delete. Pengamanan khusus juga dilakukan terhadap transaksi antar tabel yang melibat kan tabel yang saling berelasi dimana hal ini membutuhkan ketelitian dan kehati-hatian karena data saling terkait antara satu tabel dengan tabel yang lainnya.

Untuk meminimalisir terjadinya permasalahan seperti yang telah dijelaskan sebelumnya maka akan diuraikan tahapan-tahapan apa yang harus dilakukan pada database yang digunakan dalam Sistem informasi PMB. Juga akan dijelaskan hal-hal apa saja yang menjadi dasar adanya perbaikan maupun penambahan filter tertentu pada database yang digunakan pada Sistem Infomasi PMB.

\subsection{Tinjauan Pustaka}

Pemberian Constraint Check dalam basis data akan sangat membantu sebuah database dalam melakukan penyaringan data dalam sebuah transaksi. Dengan adanaya Contraint Check hanya data yang memenuhi syaratlah yang akan di proses transaksinya baik itu penambahan, pengubahan maupun dalam penghapusan data. Sehingga dengan adanya Contraint Check ini dapat menyederhanakan program antara muka yang nantinya akan dibuat [4].

Keamanan dalam sebuah database merupakan bagian penting dari desain dan fungsi dari basis data terdistribusi. Dalam sebuah basis data terdistribusi ada tiga bagian penting yaitu pyshical, User dan Network. Ketiga bagian tersebut harus saling bekerja sama dengan Policies, Standar dan procedure untuk dapat menghasilkan suatu basis data terdistribusi yang optimal. Khususnya paada bagian pyschical database harus bekerja sama dengan Standar dan Procedure tambahan untuk meningkatkan kemananan dalam sebuah database [5]. 
Salah satu cara untuk mengamankan sebuah database adalah dengan melakukan enkripsi pada sebuah database dengan menggunakan meotode pengithungan hash dan watermark. Dengan menggunakan metode ini diharapkan tidak terjadi perubahan data dan duplikasi data [6].

Kesalahan konfigurasi dan paramter dalam sebuah database telah menjadi penyebab utama kegagalan perangkat lunak. kesalahan konfigurasi akan berakibat pada tidak sesuainya data yang masuk dalam sebuah database [7].

Dari beberapa penelitian terdahulu telah dijelaskan metode yang digunakan dalam mengamankan sebuah database dan betapa pentingnya pengamanan sebuah database untuk memastikan sebuah sistem informasi dapat berjalan dengan lancar. Pada penelitian disini difokuskan pada penentuan tipe data, panjang karakter serta penggunaan Trigerr dalam validasi transaksi data.

\section{METODE PENELITIAN}

Analisa dalam keamanan dalam desain database penerimaan mahasiswa baru dalam penelitian ini akan menggunakan metode yang menjadi standard MySQL yaitu Constraint, Function serta pengguna Tipe Data. Pada penerapannya nanti fungsi yang dibuat tersebut akan di ujicoba dengan transaksi yang berkaitan dengan tabel-tabel yang akan diuji dengan melakukan pengisian data, manipulasi data bahkan hingga penghapusan data. Data yang diujicoba adalah data yang tidak sesuai dengan aturan yang telah diterapkan pada sistem informasi PMB sehingga diketahui seberapa efektifkah penerapan Constraint dan Function yang dibuat untuk memberikan keamanan pada Database yang digunakan.

\subsection{Batasan Masalah}

Agar pembahasan dalam penelitian ini tidak terlalu melebar maka penelitian akan difokuskan pada analisis berdasarkan kesalahan penentuan tipe data, analisis berdasarkan tipe data dalam transaksi tabel, analisis berdasarkan filter terhadap transaksi tabel dan analisis berdasarkan data yang salah sebelum adanya filter. Sehingga dengan adanya batasan ini dapat menjadi acuan dan menjadi salah ladasan dalam penelitian ini agar tetap berada pada titik permasalahan.

\subsection{Perancangan Deain database PMB (Peneriamaan Mahasiswa Baru)}

Dalam pelaksanaan penelitian ini menggambil skripsi dari Irwin Nugroho dengan NIM 07520244075, program studi Pendidikan Teknik Informatika Fakultas Teknik, dari Universitas Negeri Yogyakarta. Ruang lingkup database yang akan dijabarkan adalah berkitan dengan penerimaan mahasis baru (PMB). Dalam sistem informasi yang dibangun pada skripsi tersebut terdapat tujuh tabel yaitu sebagai berikut [8]:

1. Tabel User

2. Tabel Kecamatan

3. Tabel Berita

4. Tabel Sekolah Asal

5. Tabel Prestasi

6. Tabel Peserta

7. Tabel Daftar Ulang 
Citec Journal, Vol. 5, No. 4, Agustus 2018 - Oktober 2018

ISSN: 2460-4259

Ketujuh tabel tersebut kemudian akan saling berelasi satu dengan yang lainnya, adapun desain relasi antar tabel dari aplikasi PMB tersebut terlihat seperti Gambar 1 berikut [8].

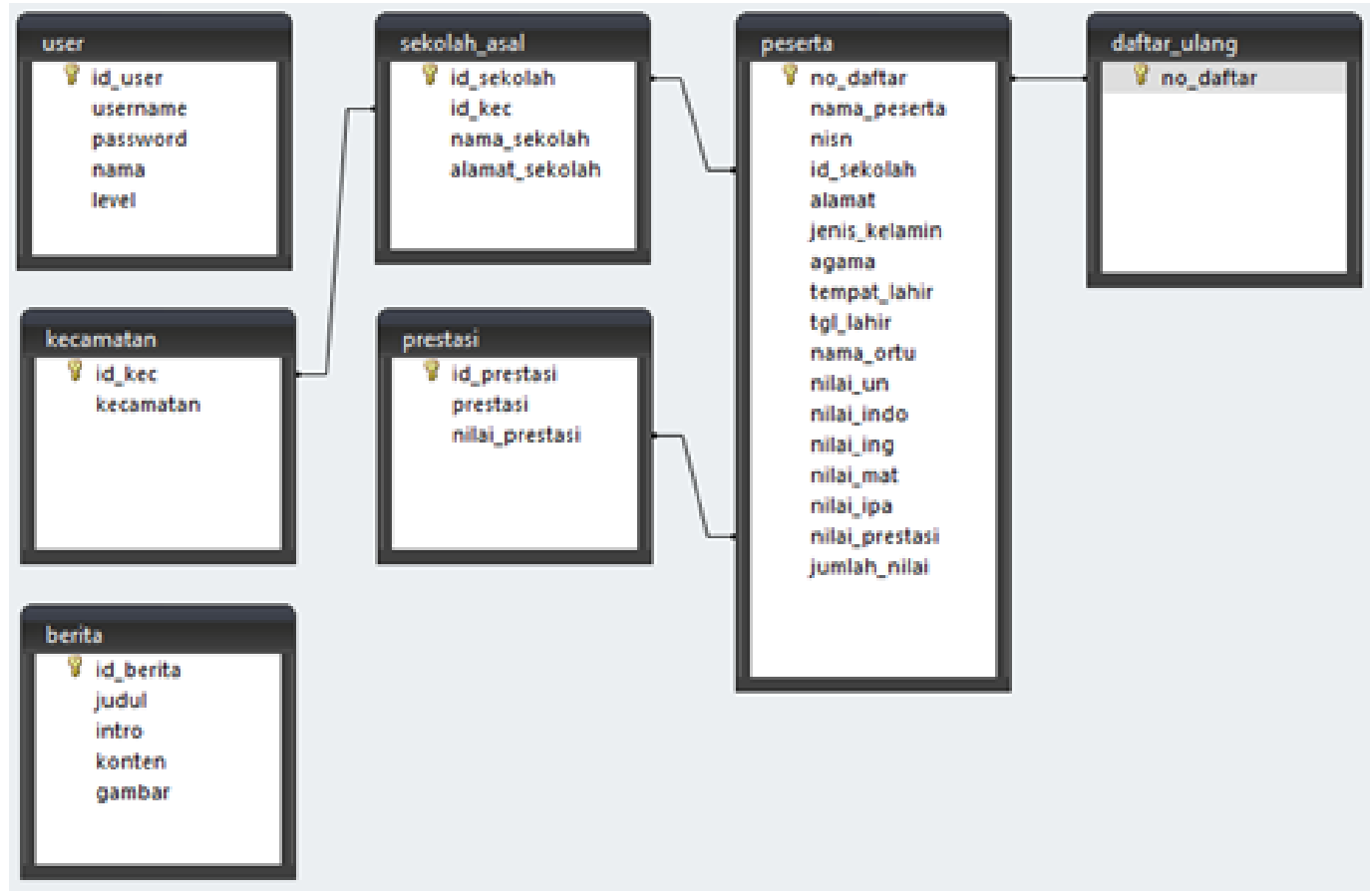

Gambar 1. Relasi Antar Tabel Database PMB

Adapun Tabel user memiliki property seperti terlihat pada Tabel 1. Pada tabel user terdapat 5 field yaitu id_user, username, password dan level, dalam tabel ini berisi data user yang berhak login kedalam aplikasi PMB.

Tabel 1. Tabel User pada database PMB

\begin{tabular}{|l|l|l|l|}
\hline Field & Type & Size & Null \\
\hline id_user $(*)$ & varchar & 5 & not null \\
\hline username & varchar & 45 & not null \\
\hline password & varchar & 45 & not null \\
\hline nama & varchar & 45 & not null \\
\hline level & varchar & 45 & not null \\
\hline
\end{tabular}

Selanjutnya terdapat tabel kecamatan yang akan menampung data kecamatan dan kode kecamatan, adapun tabelnya terlihat seperti pada Tabel 2. Tabel kecamatan terdiri dari 2 field yaitu id_kec, dan kecamatan dimana seluruh data kecamatan yang digunakan pada PMB.

Tabel 2. Tabel Kecamatan pada database PMB

\begin{tabular}{|l|l|l|l|}
\hline Field & Type & Size & Null \\
\hline id_kec $\left(^{*}\right)$ & varchar & 2 & not null \\
\hline kecamatan & varchar & 45 & not null \\
\hline
\end{tabular}

Tabel sekolah asal menampung data yang berkaitan dengan asal sekolah peserta PMB, dimana dalam tabel ini terdapat field yang saling berelasi dengan tabel kecamatan. Terdapat empat filed dalam tabel ksekolah yaitu id sekolah, id kecamatan, nama sekolah dan alamat sekolah, seperti ditunjukkan pada Tabel 3. 
Tabel 3. Tabel Sekolah asal pada database PMB

\begin{tabular}{|l|l|l|l|}
\hline Field & Type & Size & Null \\
\hline id_sekolah $\left(^{*}\right)$ & integer & 3 & not null \\
\hline id_kec $\left(^{* *}\right)$ & integer & 2 & not null \\
\hline nama_sekolah & varchar & 25 & not null \\
\hline alamat_sekolah & varchar & 45 & not null \\
\hline
\end{tabular}

Tabel peserta, ditunjukkan seperti Tabel 4, merupakan tabel utama dalam database PMB (Penerimaan Mahasiswa Baru) dimana dalam tabel ini terdapat filed-filed yang saling berelasi dengan filed dari tabel pendukung lainnya. Seluruh data perserta PMB nantinya akan ditampung dalam tabel ini sehingga bisa dikatakan tabel ini adalah tabel inti dari aplikasi PMB (Penerimaan Mahasiswa Baru).

Tabel 4. Tabel Peserta pada database PMB

\begin{tabular}{|l|l|l|l|}
\hline Field & Type & Size & Null \\
\hline no_daftar $\left(^{*}\right)$ & integer & 4 & not null \\
\hline nama_peserta & varchar & 45 & not null \\
\hline id_sekolah $\left(^{* *}\right)$ & integer & 3 & not null \\
\hline alamat & varchar & 45 & not null \\
\hline tempat_lahir & varchar & 15 & not null \\
\hline tanggal_lahir & date & & not null \\
\hline agama & varchar & 10 & not null \\
\hline nama_ayah & varchar & 45 & not null \\
\hline nilai_un & varchar & 5 & not null \\
\hline nilai_indo & varchar & 5 & not null \\
\hline nilai_ing & varchar & 5 & not null \\
\hline nilai_mat & varchar & 5 & not null \\
\hline nilai_ipa & varchar & 5 & not null \\
\hline nilai_prestasi $(* *)$ & varchar & 5 & not null \\
\hline jumlah_nilai & varchar & 5 & not null \\
\hline
\end{tabular}

Tabel prestasi nantinya akan digunakan untuk menampung data prestasi peserta PMB, dimana terdapat tiga field dalam tabel ini yaitu, id prestaso, prestasi, dan nilai prestasi, ditunjukkan pada Tabel 5.

Tabel 5. Tabel Prestasi pada database PMB

\begin{tabular}{|l|l|l|l|}
\hline Field & Type & Size & Null \\
\hline id_prestasi $(*)$ & varchar & 6 & not null \\
\hline prestasi & varchar & 45 & not null \\
\hline nilai_prestasi & varchar & 5 & not null \\
\hline
\end{tabular}

Tabel Daftar ulang hanya berisi satu field yaitu filed no daftar, yang mana no daftar sebagai primary key sekaligus sebagai foreign key, ditunjukkan pada Tabel 6.

Tabel 6. Tabel Daftar Ulang pada database PMB

\begin{tabular}{|l|l|l|l|}
\hline Field & Type & Size & Null \\
\hline no_daftar $(*)(* *)$ & integer & 4 & not null \\
\hline
\end{tabular}


Citec Journal, Vol. 5, No. 4, Agustus 2018 - Oktober 2018

Tabel berita menampung informasi serta pengumuman pada aplikasi PMB, ditunjukkan pada Tabel 7. Tabel data pada database PMB ini tidak berelasi dengan tabel manapun.

Tabel 7. Tabel Berita pada database PMB

\begin{tabular}{|l|l|l|l|}
\hline Field & Type & Size & Null \\
\hline id_berita $\left(^{*}\right)$ & integer & 4 & not null \\
\hline judul & text & & not null \\
\hline intro & text & & not null \\
\hline konten & text & & not null \\
\hline gambar & text & & not null \\
\hline
\end{tabular}

Adapun Code SQL dalam pembuatan database PMB adalah sebagai berikut.

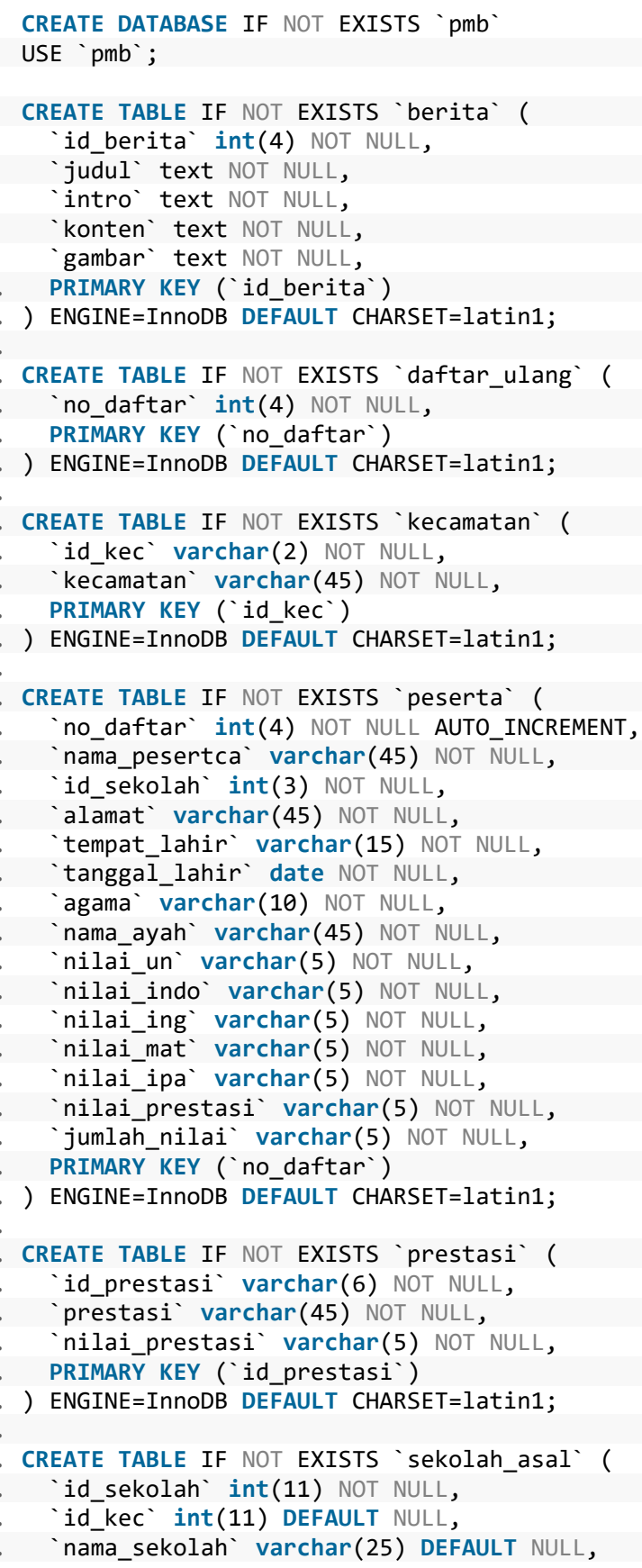




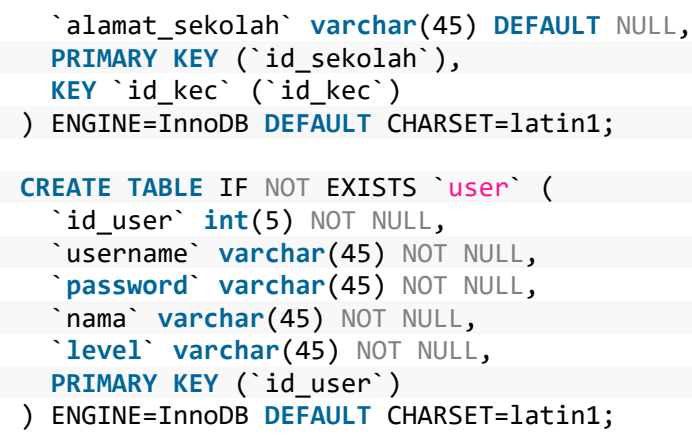

\section{HASIL DAN PEMBAHASAN}

\subsection{Analisis Keamanan Database PMB}

\subsubsection{Analisis Berdasarkan Kesalahan Penentuan Tipe Data}

Pembatasan Transaksi data dengan basis data disamping menjamin keakuratan data juga dapat meingkatkan keamanan data. Sebuah sistem informasi yang memiliki basis data yang baik akan menjadi pondasi yang kuat bagi pengembangan sistem informasi tersebut [9]. Dari Tabel 1 tersebut ada beberapa point yang menjadi sorotan antara lain. Untuk username panjang karakternya harusnya tidak sampai 45 karakter, karena pada umumnya penggunaan username dibawah 20 karakter. Untuk field nama panjangnya dapat di set ke 30 karakter. Untuk field level bisa menggunakan integer dengan panjang 1 karakter jika level menggunakan angka, atau bisa menggunakan tipe data enum jika level sudah ditentukan sebelumnya contoh (admin, pegawai).

Dari tabel asal sekolah (tabel 3) ada beberapa point yang menjadi sorotan diantaranya, id_sekolah seharusnya bisa menggunakan NPSN (nomor pokok sekolah nasional). Adapun NPSN (nomor pokok sekolah nasional) dapat diakses di alamat http://referensi.data.kemdikbud. go.id/index11.php. Selain penggunaan kode NPSN panjang karakter untuk id_sekolah juga harus dibatasi sesuai NPSN sepanjang 8 karakter. Tampilan NPSN ditunjukkan seperti Gambar 2.

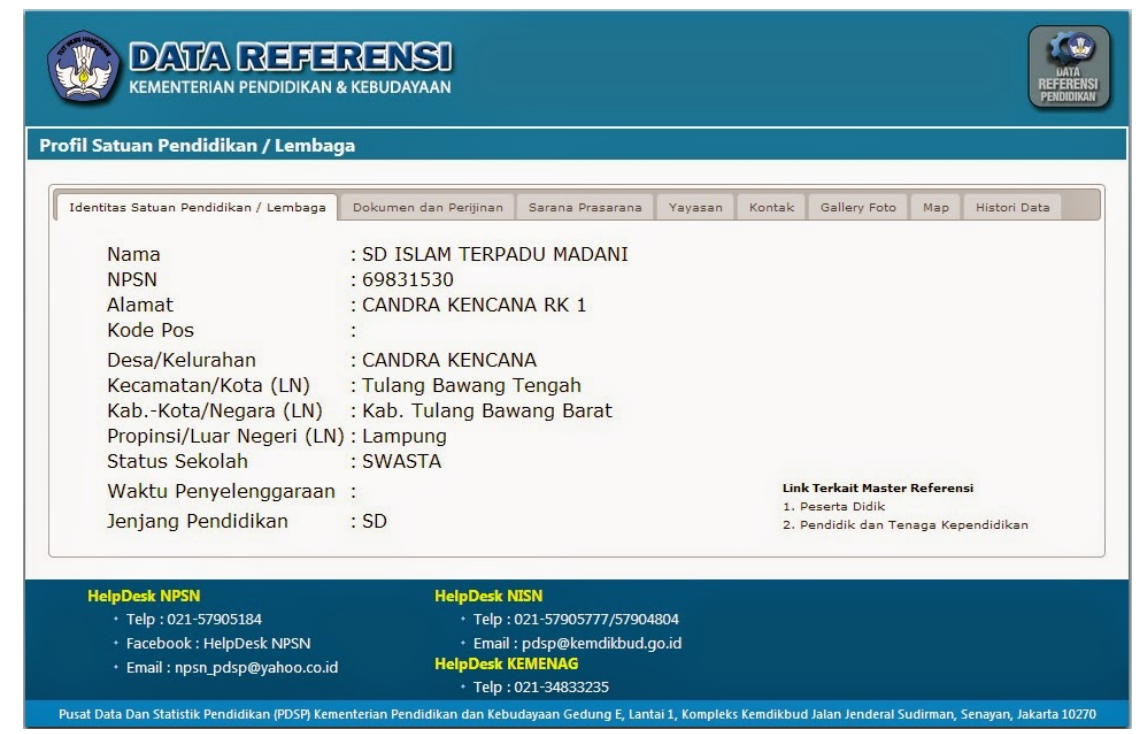

Gambar 2. Tampilan NPSN dari Website Kemendikbud

Kemudian untuk field alamat sekolah harusnya menggunakan tipe data text, hal ini dilakukan untuk mengantisipasi jika alamat sekolah cukup panjang dan lebih dari 45 karakter. Sedangkan untuk id_kecamatan bisa langsung menggunakan kode kecamatan dari kemendagri 
Citec Journal, Vol. 5, No. 4, Agustus 2018 - Oktober 2018

yang dapat diakses pada alamat berikut http://www.kemendagri.go.id/pages/data-wilayah, adapun panjang kode kecamatan nasional berdasarkan data dari kemendagri adalah 13 karakter, seperti ditunjukkan pada Tabel 8.

Tabel 8. Tampilan data kecamatan Nasional Kemendagri

\begin{tabular}{|c|c|c|c|c|c|c|c|c|}
\hline \multirow[t]{2}{*}{ Kode } & \multirow{2}{*}{$\begin{array}{l}\text { Nama } \quad \text { Provinsi/ } \\
\text { Kabupaten/ Kota }\end{array}$} & \multicolumn{2}{|c|}{ Jumlah } & \multicolumn{3}{|c|}{ Nama/jumlah } & \multirow{2}{*}{\begin{tabular}{|l|}
$\begin{array}{l}\text { Luas } \\
\text { Wilayah } \\
\left(\mathrm{Km}^{2}\right)\end{array}$ \\
586,28 \\
\end{tabular}} & \multirow{2}{*}{\begin{tabular}{|l|}
$\begin{array}{l}\text { Jumlah } \\
\text { Penduduk } \\
\text { (Jiwa) }\end{array}$ \\
445.655 \\
\end{tabular}} \\
\hline & & Kab & Kota & Kec & Kel & Desa & & \\
\hline 34 & D.I. Yogyakarta & & & 12 & 1 & 87 & & \\
\hline 34.01 & Kab Kulon Progo & & & Temon & - & 15 & & \\
\hline 34.01.01.2001 & & & & & & 1 Jangkaran & & \\
\hline 34.01 .01 .2002 & & & & & & 2 Sindutan & & \\
\hline 34.01 .01 .2003 & & & & & & 3 Palihan & & \\
\hline 34.01 .01 .2004 & & & & & & 4 Glagah & & \\
\hline 34.01 .01 .2005 & & & & & & 5 Kalidengen & & \\
\hline 34.01 .01 .2006 & & & & & & 6 Plumbon & & \\
\hline 34.01 .01 .2007 & & & & & & 7 Kedundang & & \\
\hline 34.01.01.2008 & & & & & & 8 Demen & & \\
\hline 34.01 .01 .2009 & & & & & & 9 Kulur & & \\
\hline 34.01 .01 .2010 & & & & & & 10 Kaligintung & & \\
\hline 34.01.01.2011 & & & & & & 11 Temon Wetan & & \\
\hline 34.01 .01 .2012 & & & & & & 12 Temon Kulon & & \\
\hline 34.01.01.2013 & & & & & & 12 Kebon Rejo & & \\
\hline 34.01 .01 .2014 & & & & & & 14 janten & & \\
\hline 34.01 .01 .2015 & & & & & & 15 karangwuluh & & \\
\hline
\end{tabular}

Pembahasan selanjutnya adalah mengenai tabel Daftar ulang dimana pada tabel ini hanya terdapat satu field, hal ini tentu menjadi rancu karena jika hanya menggunakan satu field, seharusnya tabel daftar ulang bisa digabung ke tabel pendaftaran peserta pmb.

\subsubsection{Analisis Berdasarkan Tipe Data Dalam Transaksi Tabel}

Membatasi input data agar data yang datang sesuai dengan persyaratan dan pengaturan yang ditetapkan adalah salah satu cara untuk menjaga integritas basis data, karena basis data merupakan sumber informasi utama yang digunakan oleh sebuah sistem informasi [10]. Kesalahan penentuan tipe data pada database akan berakibat fatal pada sistem informasi yang dibangun. Kesalahan penentuan tipe data juga berakibat data yang masuk tidak sesuai dengan kebutuhan data yang diharapakan, terlebih jika tidak diterapkan filter pada aplikasi yang ada. Untuk meminimalisir kesalahan serta ketidak sesuaian data yang masuk ke dalam sebuah database maka harus dilakukan perencanaan yang cukup matang dalam penentuan tipe data dalam database. Sebagai contoh kesalahan penentuan tipe data dalam desain database PMB bisa dilihat pada tabel perserta (tabel 4), pada field nilai_un hingga jumlah_nilai terlihat tipe data yang digunakan adalah varchar dan panjang karakter sebanyak 5 karakter seperti pada Tabel 9.

Tabel 9. Tampilan tipe data field Nilai

\begin{tabular}{|l|l|l|l|}
\hline Nilai_un & Varchar & 5 & Not null \\
\hline Nilai_indo & Varchar & 5 & Not null \\
\hline Nilai_ing & Varchar & 5 & Not null \\
\hline Nilai_ipa & Varchar & 5 & Not null \\
\hline Nilai_prestasi (**) & Varchar & 5 & Not null \\
\hline Jumlah_nilai & Varchar & 5 & Not null \\
\hline
\end{tabular}


Hal ini berakibat pada saat terjadi transaksi pada tabel peserta baik input data maupun update data, ada data yang tidak sesuai dengan kebutuhan yang tersimpan ke dalam data peserta khususnya pada field nilai.

\subsubsection{Proses pengujian sebelum ditambahkan filter}

Proses pengujian dilakukan dengan memasukan nilai_un dengan huruf hal ini dimaksudkan untuk melihat hal yang terjadi jika terjadi kesalahan penginputan dalam penggunaan aplikasi. Adapun perintah yang digunakan adalah sebagai berikut.

1. INSERT INTO 'peserta

2. ('no_daftar', 'nama_pesertca', 'id_sekolah', 'alamat', 'tempat_lahir', 'tanggal_lahir', 'agama', 'nilai_un',' 'nilai_indo', 'nilai_ing', 'nilai_mat', 'nilai_ipa', 'nilaí_prestas i', 'jumlah_nilai')

3. VALUES

4. ('2', 'Budi', '1', 'Jalan Listrik, Medan', 'Sergei', '2018-01-

01', 'Apa Saja', 'AAA', 'BBB', 'CCC', 'DDD', 'EEE', 'FFF', 'GGG');

Dikarenakan adanya kesalahan dalam penentuan tipe data maka, transaksi di atas akan dijalankan begitu saja oleh MySQL, dan data akan disimpan ke dalam database, meskipun data yang dimasukan tidak sesuai dengan kebutuhan, ditunjukkan pada Gambar 3.

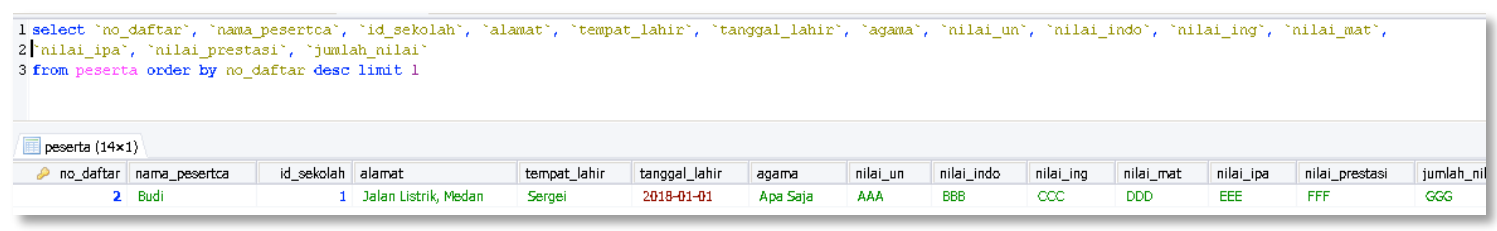

Gambar 3. Tampilan Data yang tidak sesuai berhasil dimasukan ke database

Solusi untuk mengatasi adalah dengan mengubah tipe data dari Varchar menjadi Float, hal ini dilakukan untuk meminimalisir ketidak sesuaian data yang di masukan ke dalam sistem. Adapun syntax untuk menganti tipe datanya adalah sebagai berikut.

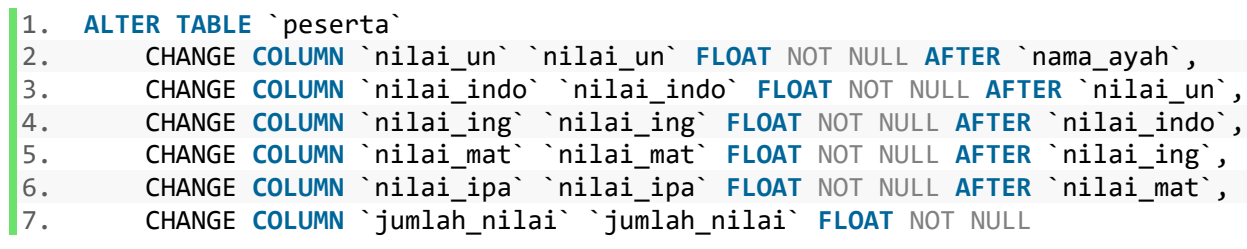

\subsubsection{Proses pengujian sesudah ditambahkan filter}

Setelah dilakukan penggantian tipe data selanjutnya akan dilakukan percobaan apakah masih bisa memasukan data yang tidak sesuai dengan aturan, berikut syntaxnya.

1. INSERT INTO 'peserta'

2. ('no_daftar', 'nama_pesertca', 'id_sekolah', 'alamat', 'tempat_lahir', 'tanggal_lahir', 'agama', 'nilai_un',' 'nilai_indo', 'nilai_ing', 'nilai_mat', 'nilai_ipa', 'nilaí_prestas i`, 'jumlah_nilài')

3. VALUES

4. ('3', 'Badu', '1', 'Jalan Listrik, Medan', 'Sergei', '2018-01-

01 ', 'Apa Saja', 'AAA', 'BBB', 'CCC', 'DDD', 'EEE', 'FFF', 'GGG');

Adapun tampilan data yang dicoba dimasukan ke dalam database terlihat seperti Gambar 4 berikut. Meskipun kita memasukan nilai AAA, BBB dan karakter lainnya maka database secara otomatis menggantinya menjadi angka 0 (nol). 
Citec Journal, Vol. 5, No. 4, Agustus 2018 - Oktober 2018

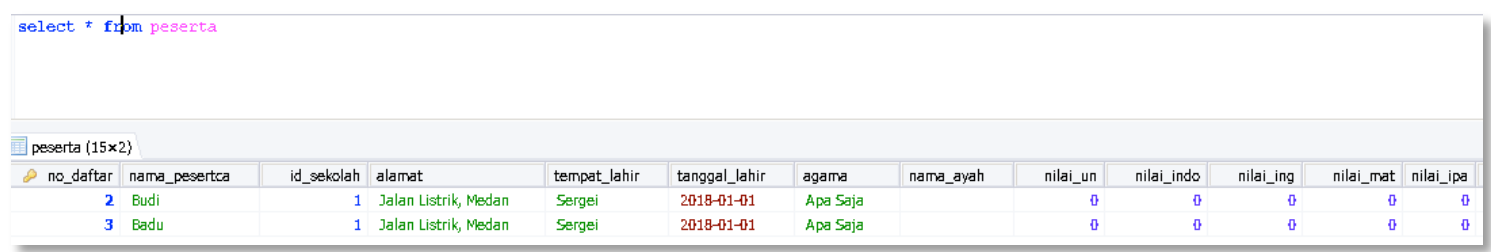

Gambar 4. Tampilan Data yang tidak sesuai berhasil dimasukan ke database

\subsubsection{Analisis Berdasarkan filter Terhadap Transaksi Tabel}

Pada penerapannya pemilihan tipe data yang baik saja masih belum cukup untuk mengatasi ketidak sesuaian data. Tentu dengan pemilihan tipe data yang baik kesalahan dalam transaksi data akan dapat di minimalisir. Banyak kasus dimana terkadang dalam transaksi data masih banyak data yang masih belum sesuai meskipun sudah diterpakan filter yang berupa penentuan tipe data yang baik.

Pemberian pembatasan data yang diinputkan dapat mencegah terjadinya exploitasi antar muka program ke suatu basis data. Kesalahan dalam pembuatan program antar muka yang melakukan komunikasi ke server basis data dapat menyembabkan munculnya kerawanan keamanan terhadap data yang disimpan, salah satu bentuk kerawanan tersebut adalah serangan SQL Injection [11].

\subsubsection{Proses pengujian sebelum ditambahkan filter}

Tahap selanjutnya akan dilakukan pengujian dengan memasukan angka yang tidak sesuai dengan standar nilai. Jika disini standar nilai yang digunakan adalah 0 sampai dengan 10. Data yang akan dimasukan yaitu data yang bernilai minus dan data dengan nilai lebih besar dari 10 .

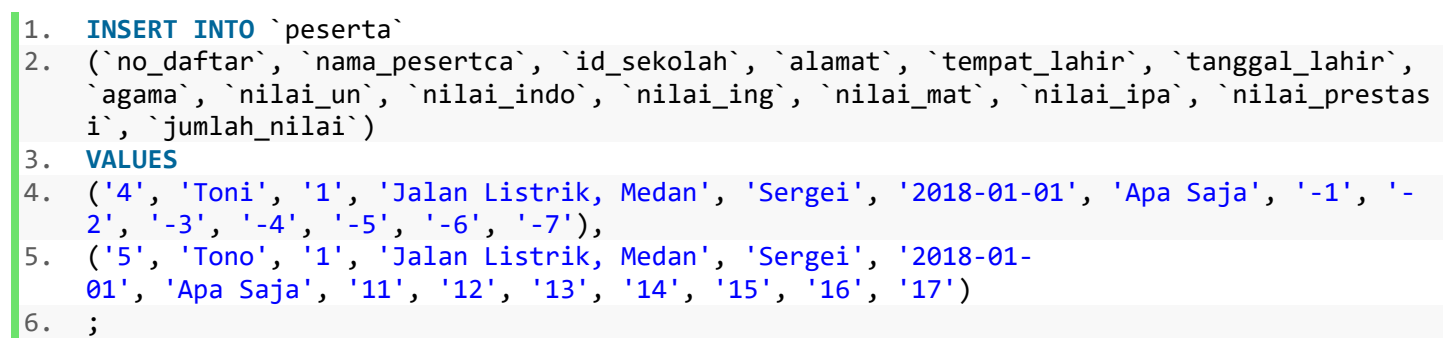

Dari syntax di atas data tersebut berhasil masuk kedalam database meskipun bernilai minus dan bernilai lebih besar dari 10, seperti yang terlihat pada Gambar 5.

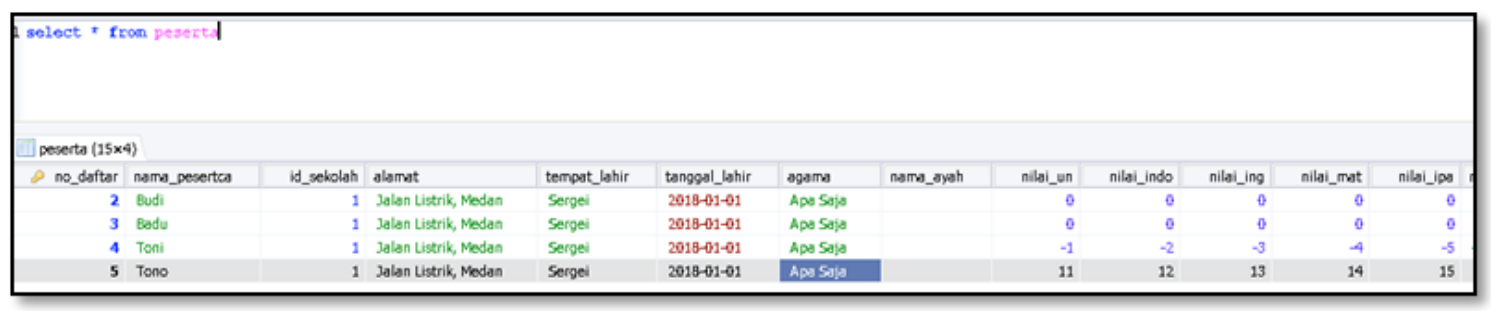

Gambar 5. Tampilan Data minus dan lebih besar dari sepuluh 
Untuk mengatasi hal tersebut akan dibuat sebuah constraint trigger untuk mengecek bahwa nilai yang dimasukan harus lebih kecil sama dengan sepuluh dan lebih besar sama dengan nol, serta nilai tidak boleh kosong dan tidak boleh null. Berikut syntaxnya.

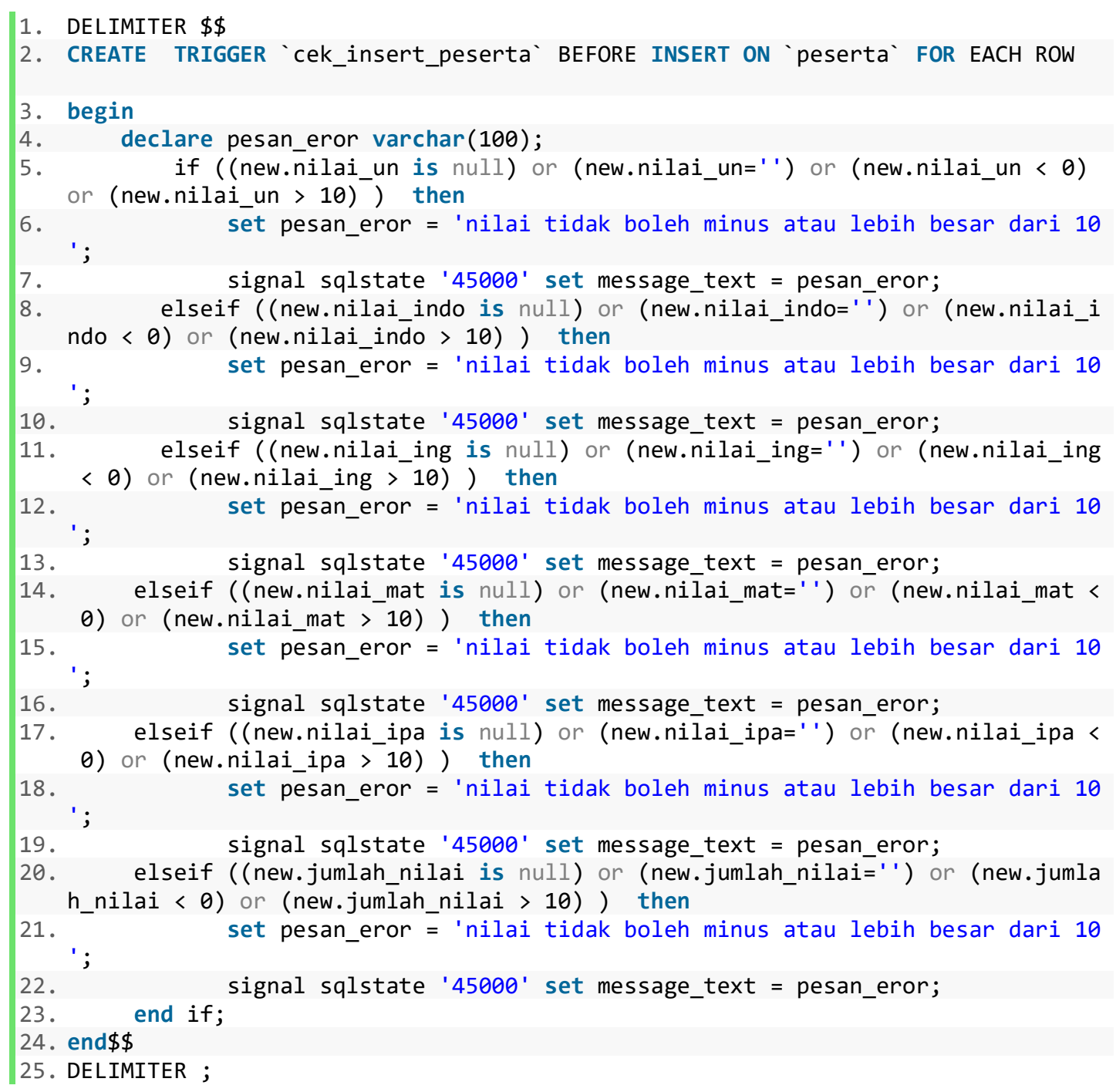

\subsubsection{Proses pengujian sesudah ditambahkan filter}

Trigger tersebut berfungsi untuk memastikan bahwa nilai yang dimasukan bernilai antara 0 (nol) hingga 10 (sepuluh). Adapaun akan dilakukan uji coba dengan memasukan nilai minus dan lebih besar dari 10, dengan syntax sebagai berikut.

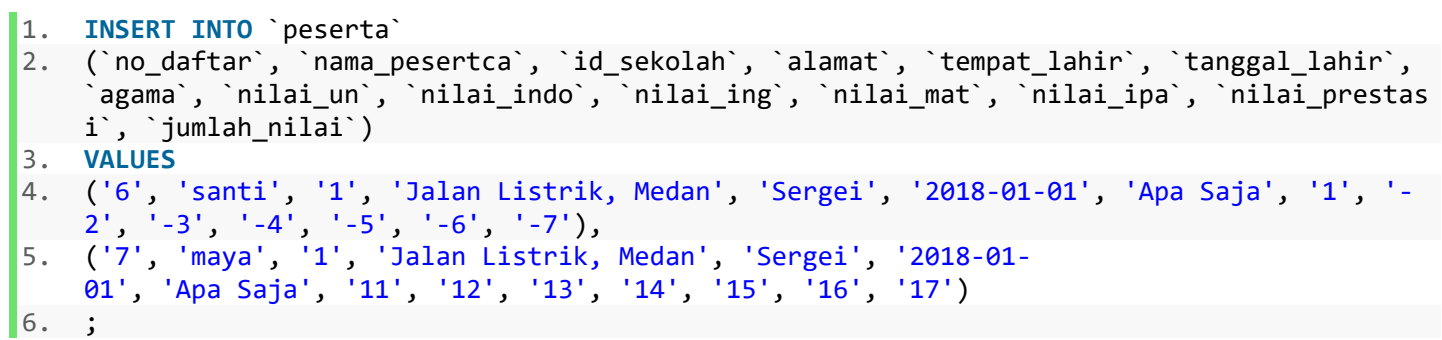


Setelah dijanlankan maka akan muncul pesan notifikasi yang tidak memperbolehkan data untuk di simpan di dalam database, seperti terlihat pada Gambar 6 berikut.

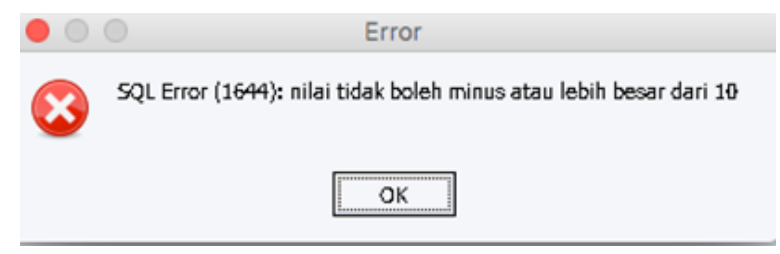

Gambar 6. Tampilan Pesan Error Filter MySQL

Untuk memastikan apakah data benar-benar masuk atau tidak, dapat dilihat tampilan tabel peserta, seperti terlihat pada Gambar 7.

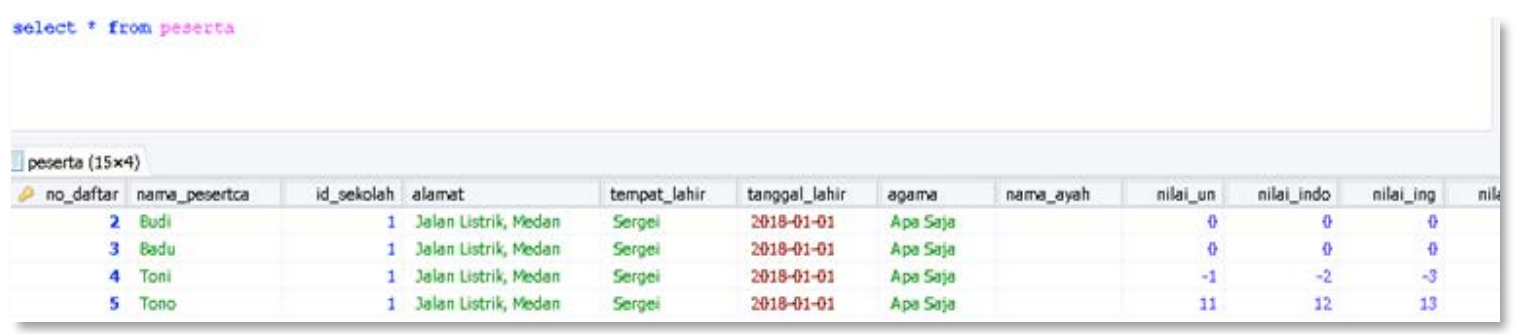

Gambar 7. Tampilan Data Tidak berubah, karena data gagal disimpan

Penerapan Trigger Check tidak hanya bisa diletakan pada saat proses input data namun juga bisa digunakan untuk melakukan pengecekan pada saat terjadi perubahan data.

\subsubsection{Analisa Berdasarkan Data yang salah sebelum Adanya Filter}

Sebuah database yang baik tidak terlepas dari pemahaman dan metode yang digunakan dalam merancangnya terutama bagaimana melakukan setiap langkah dalam fase DBLC (Data Base Life Cycle) [12]. Untuk menghilangkan ambiguitas data dalam sebuah database tidak terlepas dari proses normalisasi database yang dilakukan dengan pengubahan data sesuai dengan aturan yang berlaku [13].

Sejauh ini penerapan filter yang dilakukan pada saat transaksi data dalam tabel sudah berjalan cukup baik, namun terdapat sebuah masalah yaitu data sudah terlanjur diisi kedalam tabel sebelum diterapkan filter masih belum sesusai dengan data yang diharapkan. Salah satu contoh data yang masih belum sesusai terlihat seperti Gambar 9. Pada baris ke tiga ada data yang masih bernilai minus dan ada data yang bernilai lebih dari 10. Untuk mengatasi hal ini maka perlu dibuat sebuah perintah untuk memperbaiki data dengan catatan data yang bernilai minus di rubah menjadi nol sedangkan data yang lebih dari sepuluh diubah menjadi sepuluh. Dengan kata lain data tidak boleh melewati ambang batas tertinggi dan batas terendah.

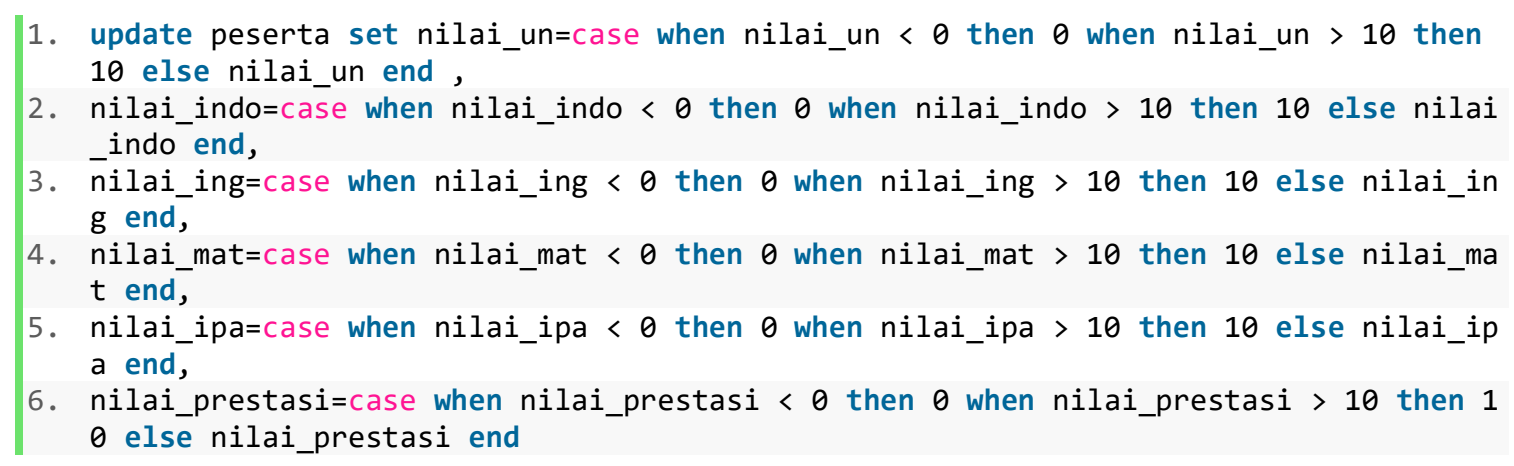




\section{KESIMPULAN}

berikut.

Berdasarkan penelitian yang telah dilakukan maka dapat ditarik kesimpulan sebagai

1. Dari hasil pengujian yang dilakukan sebelum ditambahkan parameter tipe data dan check data yang berupa huruf dan karakter masih bisa dimasukan kedalam database. Tidak hanya sampai disitu angka minus dan lebih dari 10 juga masih bisa dimasukan kedalam database. Namun setelah ditambahkan filter hanya angka dengan range 1-10 yang bisa dimasukan kedalam database.

2. Dari hasil pengujian juga dilakukan penginputan data yang salah setelah ditambahkan parameter tipe data dan check, hasil yang didapatkan meskipun data salah dipaksa untuk masuk kedalam database hasilnya data tersebut tetap gagal disimpan. Ujicoba dilakukan dengan memasukan data minus $-2,-3,-4,-5,-6,-7$ dan data melebihi angka 10, yaitu 12,13,14,15,16,16,17 angka tersebut merupakan angka diluar batas nilai un yang diberikan.

3. Jika sudah dilakukan filter dari penentuan tipe data dan panjang karakter, terkadang masih ada data yang kurang sesuai yang masuk ke dalam database, untuk itu perlu diperlukan filter tambahan check, Penggunaan Constraint Check selain menjamin keakuratan data juga menjamin keamanan data.

\section{SARAN}

Dengan adanya penelitian ini diharapakan, dapat dimanfaatkan sebagai salah satu referensi dalam desain sebuah database. Juga diharapkan adanya perhatian khusus dalam penentuan tipe data serta dalam pembuatan database. Penambahan constraint check juga perlu ditamhakan bila memang diperlukan, guna meningkatkan keakuratan data dan keamanan data.

\section{DAFTAR PUSTAKA}

[1] Sudarma, S., 2010, Panduan Belajar Database MySQL Database Server, Mediakita, Jakarta

[2] Kristanto, K. H., 1993, Konsep dan Perancangan Database, Andi Publisher, Yogyakarta.

[3] Raharjo, S., Sutanta, E., Utami, E., 2007, Analisis Aspek-Aspek Kualitas Schema Database (Studi Kasus Pada Database Akademik Ista Yogyakarta), Andi Publisher, Yogyakarta.

[4] Utami, E., 2014, The Advantages of Using CHECK Constraintsin the Academic Database Tables, Yogyakarta, Journal of Software, No. 2, Vol. 9, Hal. 382-386

[5] Zhang, T., Xing-jun, S., 2013, Status Quo and Prospect on Mobile Database Security, Telkomnika, No. 9, Vol. 11, Hal. 4949-4966

[6] Yunus, M. A. M., Krishnan, S. K. V. G., Nawi, N. M., Surin, E. S. M., 2017, Study on Database Management System Security Issues, JOIY International Journal on Informatics Visualization, No. 4, Vol 1, hal. 192-194

[7] Zhou, S., Li, S., Liu, X., Xu, X., Zheng, S., Liao, X., Xiong, Y., 2017, Easier Said Than Done: Diagnosing Misconfiguration via Configuration Constraints Analysis: A Study of the Variance of Configuration Constraints in Source Code, EASE'17, Karlskrona, Sweden, June $15-16$.

[8] Nugroho, I., 2011, Sistem Informasi Penerimaan Siswa Baru Berbasis Web dengan PHP dan SQL, Skripsi, Fakultas Teknik, Universitas Negeri Yogyakarta (UNY), Yogyakarta. 
Citec Journal, Vol. 5, No. 4, Agustus 2018 - Oktober 2018

[9] Raharjo, S., 2012, Constraint Basis Data sebagai Fondasi yang Kuat Dalam Pengembangan Sistem Informasi, Prosiding Seminar Nasional Aplikasi Sains \& Teknologi (SNAST) 2012, Yogyakarta, 3 November.

[10] Utami, E., Raharjo, S., 2014, Database Security Model in the Academic Information System, International Journal of Security and its Applications, No. 3, Vol. 8, Hal. 163-174

[11] Raharjo, S., 2013, Integrity Constraint Basis Data Relasional Dengan Menggunakan PL/PgSQL Dan Check Constraint, Semnas TEKNOMEDIA 2013, Yogyakarta, 19 Januari.

[12] Gat, 2015, Perancangan Basis Data Perputakaan Sekolah dengan Menerapkan Model Data Relasional, Citec Journal, No. 4, Vol. 2, Hal. 304-315.

[13] Hardita, V. C., Yunita, S., Sholeha, E. W., Hasan, P., 2018, Perencanaan Basis Data pada Sistem Reservasi Hotel Tickle Yogyakarta, Seminar Nasional Sistem Informasi dan Teknologi Informasi 2018 (SENSITEK 2018), STMIK Pontianak, 12 Juli 2018 